\title{
Kunstneres personlige kunnskapslandskap
}

\section{Fortellingssammenstilling som strategi i analyse av kunstneres utemmede fortellinger om begynnelser på skapende prosesser}

\author{
Anna-Lena Østern* \\ Norges teknisk-naturvitenskapelige universitet NTNU
}

\begin{abstract}
Sammendrag
Samtaler med skapende kunstnere om deres bakgrunn i livserfaringer, og om hvordan de skaper form og uttrykk, har utgjort eksempelmaterialet i denne artikkelens metodologiske drøfting. Begreper i drøftingen er hentet både fra performativ tilnærming og narrativ forskning. Forskningsspørsmålet i den delstudien denne artikkelen bygger på, er: Hva bidrar fortellingssammenstilling med som strategi i undersøkelse av kunstneres kunnskapslandskap? Skriving og formidling gjennom bruk av fragmenter og minner formet til narrative vignetter, er sammenstilt og lagt horisontalt ved siden av hverandre i analysen som utemmede fortellinger. Fragmenter fra livsfortellinger har gitt innblikk i et narrativt rom med tidsdimensjon, kontekstdimensjon og sosialitetsdimensjon i hver enkelt kunstners kunnskapslandskap, og dermed også kunnskap om hvordan kunstnere eksperimenterer ut fra sine erfaringer i engasjerte, skapende prosesser. Det personlige, profesjonelle kunnskapslandskapet er i stadig omforming, avhengig av materialitet på ulike måter: objekter, naturkultur, sansninger. Strategien fortellingssammenstilling gjør det mulig å synliggiøre hvordan temaer knyttet til affekt og kroppsstemninger, veileder kunstneren i kunstneriske valg. Hver kunstner har som hovedtema i sitt kunnskapslandskap å ville bidra med noe inn i verden.
\end{abstract}

Nøkkelord: kunstneres skapende prosesser; utemmede fortellinger; fortellingssammenstilling; kroppsstemninger; narrativt rom; kunnskapslandskap

\begin{abstract}
Conversations with artfully creative artists about their background experiences, and about how they create form and expression function as examples in the methodological discussions of this article. The analytical concepts in this discussion emanate from performative approach as well as narrative research.

The research question in this sub study is: What does story constellation as strategy contribute in exploration of the knowledge landscapes of creative artists?
\end{abstract}

^Korrespondanse: Anna-Lena Østern, Institutt for lærerutdanning, NTNU 7491 Trondheim. Epost: anna.1.ostern@ntnu.no

(C) 2018 A.L. Østern. This is an Open Access article distributed under the terms of the Creative Commons Attribution 4.0 International License (http://creativecommons.org/licenses/by/4.0/), allowing third parties to copy and redistribute the material in any medium or format and to remix, transform, and build upon the material for any purpose, even commercially, provided the original work is properly cited and states its license.

Citation: A.L. Østern. "Kunstneres personlige kunnskapslandskap - Fortellingssammenstilling som strategi i analyse av kunstneres utemmede fortellinger om begynnelser på skapende prosesser". Fournal for Research in Arts and Sports Education, Special Issue: "A forske med kunsten» Vol. 2, 2018, pp. 139-153. http://dx.doi.org/10.23865/jased.v2.1132139 


\section{A.L. Østern}

Textual communication through the use of memories of experiences form short narrative constructions and narrative vignettes which are placed horizontally alongside the analysis, as story constellation.

From the perspective offered by these vignettes the reader gets insight into the time dimension and the context dimension as well as the social dimension in the knowledge landscape of each artist, and hence, also knowledge regarding how artists experiment with their experiences in engaged creative processes. The personal professional knowledge landscape is in continuous transformation, dependent on materiality in different ways: objects nature-culture, moods. The strategy story constellation makes visible how themes connected to affect and body moods guide the artist in artistic choices. Every single artist has as a main theme in their personal knowledge landscape a wish to contribute something to the world.

Keywords: creative processes among artists; untamed stories; body moods; narrative space; story constellation; knowledge landscape

Received: January, 2018; Accepted: February 2018; Published: March, 2018.

\section{Om å forske med skapende kunstnere - en forståelsesramme}

I forskningsprosjektet «Utemmede fortellinger» har jeg samtalt med kunstnere om deres skapende prosesser. Jeg har på en måte forsket med kunstnere om deres erfaringer og eksperimenteringer med disse erfaringene. Artikkelens fokus ligger på et metodologisk plan, nærmere bestemt hvordan det å undersøke betydningen av kunstneres livserfaringer og innsikt i hvordan kunstneres skapende ideer fødes, kan legge grunnlaget for et analytisk verktøy for å belyse betydningen av bakgrunn i livserfaringer. Jeg introduserer fire analytiske begreper knyttet til narrativ forskning, nemlig utemmede fortellinger, fortellingssammenstilling, kunnskapslandskap og kompleksitet $i$ et narrativt rom. Jeg skaper også en forståelsesramme bygd på performativ teori om å skape kunstnerisk uttrykk gjennom eksperimentering med personlige erfaringer.

\section{Skapende kreative individer}

Kunstneres liv og levemåter gis mye spalteplass i den kulørte pressen, men også seriøse journalister, utdannere og forskere er tiltrukket av og nysgjerrige på den skapende prosessen hos kunstnere. Det finnes populært skrevne bøker om samtaler med kjente kunstnere som for eksempel Think like an artist... and lead a More Creative, Productive Life (Gompertz, 2015). Gompertz er kunstredaktør ved BBC og har hatt samtaler med mange kunstnere. Han sammenfatter i boken karakteristiske trekk ved navngitte kunstnere på følgende måte: de er entreprenørielle, de mislykkes (ikke), men har en plan B, de er seriøst nysgjerrige, de stjeler ideer, de er skeptiske, de tenker det store bildet og den lille detaljen, de tar et standpunkt, de er modige, de tar pauser for å tenke. Av forskningsorientert litteratur vil jeg nevne Behind the scenes of artistic creativity. Processes of Learning, Creating and Organizing (Chemi, Borup Jensen \& Hersted, 2014). Boken er også basert på intervjuer med kunstnere og gir en introduksjon til forskningsfeltet. 


\section{Performativ tilnærming}

Med performativ tilnærming og bruk av kunst som linse gjennom hvordan vi forstår verden, åpnes nye og spennende steder for teori og forskning, med mer og mer utviskede disiplingrenser i forskning. Gergen og Gergen (2018, s. 54-55) har gitt tre begrunnelser for det de kaller "the performative movement in social science». Performativt arbeid retter for det første oppmerksomhet mot hvordan forskning kan presenteres på lignende måte som kunst - for andre, hvor man spør for hvem noe skapes og hvorfor. Performativt arbeid er for det andre også sensitivt for forskningens resultat som potensiell handling i den sosiale verden. Spørsmål som er relevante kan være hva slags liv forskere og kunstnere bidrar til, og for hvem og hva dette har verdi. Den tredje motiveringen er knyttet til forskerens posisjonering som ikke-objektiv eller distansert:

In contrast, performatively oriented scholars are often quite revealing of their values and preferences; they emphasize excitement, and the potential of change, they call on artistic skills. These are essentially the skills of an artistic performer. (Gergen \& Gergen, 2018, s. 55)

Når et nytt terreng for performativ forskning utformes, nevner Gergen og Gergen (2018, s. 59) tekstlig uttrykksfullhet som en måte å utforske/eksperimentere med performativt potensial på gjennom dialogisk skriving, poetisk skriving og giennom narrativer.

McCormack (2014, s. ix) som humangeograf, legger vekt ved det performative ut fra et kunstnerisk perspektiv og løfter fram danseres kroppsliggjorte erfaringer fra affektive plasser som utgangspunkt for eksperimenteringer med nettopp erfaringer. I denne artikkelen forstår jeg kunstnernes erfaringer som knyttet til kroppsstemninger fra affektive plasser. McCormack (2014, s. 37-41) skriver videre om det affektive som fornemmelse av muligheten at noe skjer også om det er vanskelig å fange, som de tanker som holder på å formes, før de er artikulert eller bevisst. McCormack (2014, s. 75-76) siterer Batesons forståelse av hva kunstnerisk ferdighet er:

Artistic skill is the combination of many levels of mind - unconscious, conscious, and external - to make a statement of their combination. It is not a matter of expressing a single level.

McCormack legger vekt på atmosfære som noe som skapes i relasjonen mellom engasjerte kropper i bevegelse, i relasjon og transformasjon i tidsrom. Hans tekster fokuserer på erfaringers mangfoldige betydninger. Videre er han opptatt av muligheter for etisk inspirert engasjement i forandring i verden (McCormack, 2014, s. 23). McCormacks forståelse av det performative ut fra et kunstnerisk perspektiv har veiledet meg i undersøkelse og analyse i denne delstudien.

\section{Narrativ forskning, utemmede fortellinger og kompleksitetsorientering}

I kunstbasert forskning og i utdanningsforskning har narrativ tilnærming relativt lang tradisjon. Kunstneren forsker på sin egen prosess, av og til kombinert med 


\section{A.L. Østern}

kunstpedagogisk arbeid rettet mot utdanning (jf. for eksempel Bendiksen, 2017; Ronsley-Pavia \& Grootenboer, 2017; Kaihovirta-Rosvik, 2009; Riis, 2016).

Forskningsmaterialet i prosjektet «Utemmede fortellinger» er samtaler med ti skapende kunstnere om deres bakgrunn og beslutning om å bli skapende kunstnere, om hvordan deres ideer fødes, samt om skaping av formuttrykk. Jeg prøver ikke å skape koherens $i$ hele livsfortellinger, men isteden vise kompleksitet $i$ erfaringer og i måter å eksperimentere med erfaringer på gjennom å gjengi fragmenter av fortellinger. Derfor kaller jeg fortellingene utemmede. Sermijn, Devlieger og Loots (2008, s. 635f.) skriver, med lån av et begrep fra Herman og Veraeck, om utemmede fortellinger:

Just like the motif of a patchwork quilt, a postmodern story is characterized not by an embroidered, continuous pattern but by the juxtaposition of more or less disjunctive elements. Consequently, postmodern stories are also referred to as "untamed stories" or "les savages narratives" (Herman \& Vervaeck, 2005, p. 114).

I likhet med Montuori prøver jeg å skape forbindelse mellom mer tradisjonell narrativ tilnærming til forskning og kompleksitetsorientert tilnærming:

Connections are made between the modernist concept of organization and scholarly inquiry, and postmodern or complexity-based approaches that stress creativity as an emergent property of the relationship between order and disorder (Montuori, 2003, s. 235).

I følgende avsnitt beskriver jeg de analytiske begrepene jeg bruker i denne narrative studien av utemmede kunstnerfortellinger.

\section{Forskningsdesign}

I en narrativ tilnærming, ligger fokuset på å tenke narrativt om menneskelig erfaring. Det er erfaringene som er den drivende impulsen i narrative studier (Clandinin \& Connelly, 2000, s. 188). Inspirert av Connelly og Clandinin (1990), Clandinin og Connelly (1995), Clandinin (2013), samt Craig (2007) har jeg valgt å bruke en narrativ tilnærming kalt fortellingssammenstilling (eng. story constellation) for å beskrive personlige profesjonelle kunnskapslandskap som bevegelige, foranderlige og med dimensjoner som relasjoner og hendelser, samt med intellektuell og moralsk klangbunn.

\section{Kunnskapslandskap og narrativt rom}

Craig motiverer bruk av en landskapsmetafor på følgende måte:

[A] landscape metaphor allows us to talk about space, place, and time. Furthermore, it has a sense of expansiveness and the possibility of being filled with diverse people, things, and events in different relationships. Because we see the professional knowledge landscape as composed of relationships among people, places, and things, we see it as both an intellectual and moral landscape [...] (Craig, 2007, s. 175). 
I fortellingssammenstilling kan flere ulike fortellinger om samme tema plasseres ved siden av hverandre $i$ en juxtaposisjon slik at de kan fortelle fortellinger, som kan være til dels motstridende, til dels parallelle. Det som holder temaet sammen, er det tredimensionale narrative rommet. Valget av fragmenter av fortellinger sorteres etter tre dimensjoner i det narrative rommet, nemlig tid, kontekst/sted og sosialitet. Erfaringer giøres i tid, i en kontekst og personlig eller i sosialt fellesskap. Craig (2007, s. 176f.) skriver om sammenstilling av fortellinger om læreres kunnskap, med henvisning til Ayers, på følgende måte:

\begin{abstract}
Ayers, for instance, elaborated the relationships between and among these interacting narratives. He said: "there is, of course, not a single story to tell, but a kaleidoscope of stories, changing, flowing, crashing against one another, each one playing, light and shadow, off the others in an infinity of patterns" (Ayers, 1995, p. 155). This plethora of shifting narratives, each with a unique spiralling pattern, necessarily involves many plotlines, which, in turn, bring multiple meanings to bear on teachers' knowledge as shaped.
\end{abstract}

Gjennom å omskrive en fortelling, basert på de ulike fragmentene, vises spenninger og dilemmaer og revisjoner - og også hvordan gamle forestillinger forkastes til fordel for ny forståelse (Craig, 2007, s. 180). Broadening, burrowing og restorying er navn på tre faser i det narrative arbeidet. Disse tre begrepene forklarer jeg kort i det følgende med støtte av Clandinin og Connelly (2000, s. 76).

Broadening betyr å beskrive den større konteksten som en fortelling inngår i. Burrowing betyr å gå dypere inn i hvordan en person knytter sammen sine livserfaringer for å finne mening i dem, som øyeblikk og relasjoner i et kunnskapslandskap. Restorying fanger forandringer i profesjonelle kunnskapslandskap gjennom individers og gruppers handlinger. Å fortelle på ny og revidere fortellingen gir en mulighet til å tenke dypere over dilemmaer og utfordringer i virkelige situasjoner.

\title{
Fortellingssammenstilling
}

Det som kompleksistetsorientert fortellerteknikk bidrar med, er å tillate at fortellinger ikke er koherente, men mer usammenhengende. Fortellingene får stå som fragmenter: De må ikke snakke med en enhetlig stemme. Dette er også hva strategien fortellingssammenstilling tillater. En som innenfor narrativ forskning, slik den er formulert av Clandinin og Connelly (2000), har utviklet strategien fortellingssammenstilling, er Clandinins forhenværende forskerstudent Craig (2007). Hun har forsket på en skolereform i USA, og hun fant ut at hun ikke ville ha kun noen få stemmer til å fortelle om sine erfaringer med skolereformen hun studerte. Hun ønsket å skape dybde i sine analyser gjennom å sammenstille stemmer som kunne være meget forskjellige. Craig sammenstilte parvise fortellinger (som 'story of reform' og 'reform story'). Hun skiftet perspektiv gjennom å sammenstille enkeltindividers fortellinger om reformen ved siden av hverandre, og deretter å skape en reformfortelling om reformen hun studerte. Hun brukte de tre prinsippene med å ta inn den bredere konteksten for skole og reform, og 


\section{A.L. Østern}

å fordype analysen, samt å lage revisjoner av reformfortellingen. I denne delstudien kan på lignende måte enkeltindividers fortellinger om skapende prosesser sammenstilles horisontalt og knyttes til en fortelling om kunnskapslandskap hos skapende kunstnere.

\section{Forskningsspørsmål}

I samtalene er fokus på de skapende prosessene hos kunstnere, og forskningsspørsmålet jeg søker svar på i den delstudien denne artikkelen presenterer, kan formuleres slik: Hva bidrar fortellingssammenstilling med som strategi $i$ undersøkelse av kunstneres kunnskapslandskap?

Som kunstfagdidaktiker søker jeg gjennom en slik sammenstilling etter muligheter til å artikulere hva som driver slike prosesser, hvordan kunsten gir mening og skaper kunnskap, uten å bruke en analysemetode som reduserer meningen i de rike, komplekse kunstnerfortellingene jeg møter. Jeg søker etter "webs of significance» slik kulturantropologen Geertz uttrykker seg (Geertz, 1973, s. 5). Hensikten med å undersøke fortellingskonstellasion som mulig analysestrategi, er altså et ønske om å beholde og artikulere, ikke redusere eller dempe, rikt meningsbærende kunstneriske prosesser. Å beholde rikdommen, kompleksiteten og ofte tvetydigheten i kunstneriske prosesser ser jeg som en metodologisk utfordring for det å forske med kunsten, men samtidig som en mulighet til å beskrive kunstneres kunnskapslandskap.

\section{Forskningspersoner og strategiske valg}

Ti kunstnere med et aldersspenn fra 28 år til 72 år er forskningsdeltakere i prosjektet «Utemmede fortellinger». Forskningsdeltakerne bidrar med sine livsfortellinger der deres kunstnerskap står i fokus: en fra Danmark, en fra Frankrike, to fra Finland, seks fra Norge. Alle er på ulike måter aktive i Norge, noen også internasjonalt. Studien er allikevel avgrenset til en norsk kontekst. Utvalget er strategisk på den måten at hver kunstner representerer en spesifikk kunstform eller performativ tilnærming. Jeg har spurt personer jeg har hatt profesjonell kontakt med som lærerutdanner i ulike prosjekter, og det vil si at jeg har hatt mange samtaler med dem og kjenner deres kunstneriske og kunstpedagogiske arbeid over lang tid. Jeg har også deltatt i en del av prosjektene både som utøver, som kunstfaglig lærer og som forsker. Jeg har valgt disse ti, fem kvinner og fem menn, fordi de alle på en eller annen måte også bruker sin kunstform i forsknings- og utviklingsprosjekter knyttet til utdanning ${ }^{1}$. Med unntak av tre tilhører disse også kompanier, band, eller formaliserte kunstnergrupper. Jeg nevner den enkelte kunstners profesjonelle felt litt lenger fram i dette avsnittet.

Prosjektet er godkjent av NSD ${ }^{2}$, og deltakerne har samtykket i at de kan kjennes igjen gjennom fortellingene. Jeg har allikevel valgt å ikke bruke kunstnernes navn, men koder deltakerne (1-10), fordi det er de skapende prosessene som er i fokus.

${ }^{1}$ I forskningsprosjektet som helhet er dette av betydning, men temaet utvikles ikke i denne artikkelen grunnet artikkelens metodologiske fokus.

${ }^{2}$ Norsk samfunnsvitenskapelig datatjeneste. 
I tillegg har jeg oversatt eller tilpasset alle fortellinger til norsk bokmål. Den metodologiske interessen i denne artikkelen er de temaer som de ulike fortellingene aktualiserer, og hvordan de kan analyseres/sammenstilles for å kartlegge noe av kompleksiteten i skapende kunstneres kunnskapslandskap.

Samtalene med kunstnerne er tatt opp på PC, og jeg har transkribert samtalene i etterkant. Hver deltaker har fått lese og kommentere transkripsjon av sin samtale og har på den måten kontrollert sin fortelling. Dermed har samtalen gjennomgått en såkalt memberchecking, noe som forskningsetisk er av betydning når det gjelder individers livsfortellinger. For denne metodologisk orienterte artikkelen bruker jeg spesielt det materialet som er generert ut fra to temaer i samtalen, nemlig a) hvordan det å bli en skapende kunstner begynte, og b) hvordan ideer til skapende prosjekt fødes. Forskningsdeltakerne representerer følgende profesjoner: videokunstner, koreograf, improskuespiller, forfatter og performer, dramaturg, scenograf, låtskriver, regissør, komponist og visuell kunstner.

\section{Forskningsetiske overveielser}

Siden forskningsdeltakerne har tillit til meg som forsker, har det vært viktig for meg å utvise forskningsetisk takt: å gi tilbake transkribert tekst og konstruerte narrative vignetter til forskningsdeltakerne slik at de kan godkjenne bruk eller foreslå endringer. Min egen bakgrunn som kunstfagdidaktiker og som utøvende kan støtte opp om den troverdighet som er nødvendig for deltakernes tillit til meg med blikk både som utøvende, pedagog og forsker. Den teoretiske og metodologiske inngangen skaper også en nødvendig distanse til enkeltpersoner gjennom fokus på kartlegging av kunnskapslandskap. I det følgende har jeg valgt å arbeide analytisk med fire fortellingsfragmenter for å belyse hva fortellingskonstellasjon kan gi som resultat. Jeg innleder allikevel med ti fortettede narrative konstruksjoner, en slags kort sammenstilling av hva som karakteriserer de ti kunnskapslandskapene jeg har fått innsyn i. Disse fortettede narrative konstruksjonene gir et gløtt inn i det utemmede, dypt personlige og komplekse i skapende kunstneres kunnskapslandskap. Begynnelser på skapende prosesser er ulike. De har ulik stemning. De er knyttet til temaer av betydning, noe som skaper mening i den enkelte kunstners liv.

\section{Fortellingskonstellasjoner $i$ et narrativt rom}

Dette analyseavsnittet bygger på narrative vignetter som jeg har sammenstilt på basis av samtalen med den enkelte kunstner. Jeg har innledningsvis fra hver vignett løftet fram en setning som fortettet narrativ konstruksjon av forskningspersonens fortelling:

1. Det er det beste i verden, denne fasen når du begynner å se muligheter, linjer, bevegelse, dybde.

2. Noen ideer slår veldig rot, og så kan de ligge der mange år før de blir realisert.

3. Er det ingenting du vil ha sagt så ikke prøv å gjør det. Ti stille og gå hjem. 
4. Min skapende kraft er som en sol inni meg. Jeg føler at den aldri tar slutt.

5. Det er som et bunjyjump å overgi seg til gruppen i en improvisert forestilling.

6. Å se formen fremtre, det er en slik glede, nesten som å touche gud.

7. Jeg kan ha stjålet den første ideen til en komposisjon.

8. Mine ideer til en forestilling begynner alltid fra et ønske om å berøre.

9. Musikken er en måte å gjemme meg vekk fra minner av å bli mobbet i skolen.

10. Uten det skapende skulle livet ha mangel på mening, men nå vet jeg jeg har noe å dele.

Disse fortettede narrative konstruksjonene viser til ulike, komplekse erfaringer. Alle disse kunne bidra til å utdype forståelse for kunstnernes kunnskapslandskap. Slik Ayers (1995, s. 155) formulerte det, kaster disse fortellingene lys og skygge over hverandre. Artikkelformatet og det metodologiske fokuset gjør likevel at jeg har valgt å sammenstille kun fire av fortellingene til litt lengre narrative vignetter. Gjennom å sammenstille dimensjoner i fortellingene kan jeg gi fragmentariske bilder fra kunstneres kunnskapslandskap. Jeg tar i bruk dimensjonene tid, kontekst/sted og sosialitet $i$ et narrativt rom for å karakterisere disse kunstneres kunnskapslandskap, men jeg kan på bakgrunn av analysen også utvide det narrative rommet. De fire fortellingene utgjør en fortellingssammenstilling.

Narrativ vignett 1: Det er det beste i verden, denne fasen når du begynner å se muligheter, linjer, bevegelse, dybde.

feg er avhengig à gjøre som jeg gjorde da jeg var liten. Min far gav oss stor frihet og stort ansvar. feg begynte å kjøre traktor da jeg var 11, på gården. Og bil når jeg var 14 år. Ut å jobbe, ikke leke seg men jobbe. Før var det greit at barna var ut $i$ skogen hele dagen og leika seg, og utforska huler, og laga fordemninger $i$ elva, og klatra $i$ trcer. Det var helt fint det. Feg er helt avhengig av à vere der innimellom.

Fra mine barndomsopplevelser fins helt klart, lys og stemninger igjen. Visuell persepsjon, jeg vet ikke om det henger sammen med at jeg var ekstremt narsynt til jeg var uti andre klassen. Feg lert à lese så ingen oppdaget det for ut $i$ andre klassen. Feg hadde minus fem eller sånt. feg så ingenting. Hele barndommen var bare lys og stemninger for jeg så ikke mer enn fem meter. Resten er bare utvaskede lysfenomen. Det er jo slik i Trondheim og. Du har åtti årstider $i$ løpet av en dag. Feg har reist mye, vert $i$ femti land. Det er altfor flat dag mange steder. Feg blir helt svett av at det er helt likt en uke. Her er det hundre versjoner av farger mot fjorden, grått, blått og kobolt og skjcert- det er den dybden tror jeg som gjør noe med sanseapparatet, at det er sånn variasjon. Den svarte veggen av Fosen-alpene for eksempel.

Stemningsleiet $i$ begynnelsesfasen av et prosjekt er det beste $i$ verden. Det er ingenting som slår akkurat den idéfasen. Det å knytte sammen abstrakta, før du begynner med jobben. Når du driv og hiver opp moodboards ${ }^{3} i$ lufta $i$ hodet ditt. Det er ikke sikkert

${ }^{3}$ Ordet betyr en collage av materiale, type bilder, tekst, farger - som fanger stemning eller følelse et 'stemningsplank'. 
det lar seg gjennomføre, men du begynner å se muligheter, linjer, se bevegelser, dybde. Det er det beste $i$ verden. Derfor sitter jeg her $i$ mitt studio og ikke jobber fast noe sted. (Videokunstner)

For videokunstneren er bevegelighet i tidsopplevelse av sentral betydning. Hendelser og atmosfære fra barndommen har en sterkt formende funksjon i det skapende arbeidet i nåtid, og kunstneren ser sin nærsynthet som en ressurs han kan bruke i eksperimentering $\mathrm{i}$ forhold til sine erfaringer. Både barndommens steder, studioet og Fosen-alpenes fargespill utenfor, der han jobber alene, er til stede og av betydning $\mathrm{i}$ det eksperimenterende skapende arbeidet. Det er et sanselig, visuelt og materielt rom som utforskes performativt og prøvende, avhengig av bestillingen kunstneren jobber med. Hver prosess er en ensom personlig reise i tid og rom, med ingen tid for det sosiale. I prosessen er mulige visuelle løsninger eksperimentert fram som «muligheter, linjer, se bevegelser, dybde». Spørsmålet om hvem dette skapes for er viktig, og også de verdier han bygger inn i videoscenografien han skaper for andre kunstneres prosjekter og forestillinger.

Narrativ vignett 2: Noen ideer slår veldig rot, og så kan de ligge der mange år før de blir realisert.

Feg har alltid opplevd at jeg har hatt en skapertrang siden jeg var liten, og den skapertrangen den er en sånn grunnleggende åre $i$ mitt liv. Mine tidligste opplevelse av meg selv er å ha et veldig behov for å skape. Det trenger ikke å vare en stor ting. Bare å vare kreativ $i$ det små. For meg så er det et grunnleggende behov som jeg også har tenkt på mye, når jeg er blitt voksen, at det à skape er viktigere for meg enn å sove. Slik at jeg kan organisere hverdagen slik at jeg fär utlop for det som jeg kaller en kreativ trang eller kreativ energi, som egentlig handler om à skape form og uttrykk.

Feg har ofte folelsen av at jeg blir bombardert med koreografiske ideer, og med koreografi mener jeg da forestillinger. Du kan erstatte koreografi med regi nermest. Det er som ideer til helheter, bare det at det har et bevegelsesutgangspunkt. Feg fär veldig mange sånne ideer hver dag, men noen ideer preller bare av, mens noen ideer slär veldig rot, og så kan de ligge der mange år for de blir realisert.

En slik ting var når jeg var første gang ved Atlanterkysten, når min kjcereste tok meg med til sin bestefar. Feg traff jeg hans bestefar som hadde vert fisker, og så dro vi på en fisketur. Så satt jeg og ble kjent med denne gamle mannen, og så fikk jeg se alle de her materialene, alle fiskenettene og garnene, og gamle redskaper som så ut som de var fra 1800-talet, mye oransje farger. Og jeg satt og så ned $i$ vannet og det var så fantastisk klart, blått og turkis og sånn på bunn, og da vet jeg at jeg fikk en veldig klar idé om å gjøre en forestilling som skulle hete "Fisk». Feg så veldig for meg hvordan en slik forestilling skulle se ut, $i$ hvert fall et rammeverk til den. Det der var $i 1997$ eller 1998, og så lå bare den ideen der. Feg skrev ikke ned noe. Det er bare en idé jeg forvalter et sted, barer med meg. Det kjennes som en slags flyt, energiflyt som jeg bare har med meg. Farger og visuelle bilder. Feg hører også et lydlandskap. Feg vet hvilken stemning det her skal ha. Så dukka det opp, plutselig, en mulighet, en reell mulighet. Forestillingen «Fisk» ble ferdig 


\section{A.L. Østern}

i 2006, med viktig utprøving av ideer sammen med andre kunstnere, og med barn som prøvepublikum. (Koreograf)

Koreografens fortelling har en sterk tidsdimensjon, hvor barndomserfaringer og hendelser senere i livet flettes sammen. Det å møte kjærestens bestefar i en intensiv følelsesladet situasjon virker å ha gitt sterke sanselige impulser til skapende uttrykk. I dette fragmentet er skapertrang løftet fram som en energiflyt, som ulike affekter og stemninger. Erfaringene kan tidfestes, og de er knyttet til spesielle steder og til betydningsfulle mennesker. Erfaringene, atmosfæren og rytmen er med som "energiflyt» i den forestillingen koreografen skaper nesten ti år etter et møte, hvor hun var spesielt mottakelig for inntrykk fra møtet med den naturkonteksten kjærestens bestefar levde i. Erfaringene blir gjennom transformasjon og eksperimentering sammen med andre kunstnere formet til et kunstnerisk uttrykk med mange lag. I forestillingsarbeidet blir det sosiale viktig, både i samarbeidet med utøvende kunstnere og i utprøvning av forestillingskommunikasjon med barn som publikum.

Narrativ vignett 3: Er det ingenting du vil ha sagt, så ikke prøv å gjør det. Ti stille og gå hjem.

feg måtte få definere mine egne oppgaver som prest. Det er ikke noe prinsipielt forskjellig $i$ prosessen å utvikle og holde en preken, skrive manus til et historisk spill, eller vare performer og klovn. Feg er avhengig av den samme prosessen. Når jeg forbereder en preken må jeg sørge for at møtet med teksten og menneskene blir virkelig. Og når det gjelder performance er det den samme prosessen. Jeg har mange ganger provd à sette meg ned og lage tekster. Feg får det ikke til før jeg vet Hva skal du med den? Skaperkraften ligger ikke $i$ meg, men kommer fra at noen har bruk for ideen. Koblingen av de to. Der ligger det veldig mye for meg.

Begrunnelsen for kirke-klovnen var sorgen over den selvhøytidelige kirken rett og slett. Det tok meg ganske lang tid å komme til den klovnen - fikk vel egentlig ideen at klovnen og presten er samme sak, noe som gjorde det mulig å gjennomføre det. Feg hadde på en måte ideen, stedet og så var det motet som manglet. Men jeg tør fremdeles ikke dette. Det å på en måte bryte helt ut og risikere å bli tilintetgjort. Det kosta meg ganske mye.

For meg så er nok arbeidet med det kroppslige mye mer knyttet til performance og prekenarbeid. Feg har et knallgodt eksempel på det. Jeg har gått med øresus noen år. Og det er helt konstant. Noen ganger er det plagsomt, men jeg har bestemt at jeg skal ikke la det plage meg. Men når jeg skal inn på en scene som prest, da har jeg det ikke. Og jeg tenker, men da klarer du det. Men jeg kan ikke konsentrere meg slik at jeg kan bli kvitt den pipinga, når jeg kjører bil for eksempel. Men når jeg opptrer hører jeg det ikke, først etterpå. feg går inn $i$ de situasjonene med et slikt fysisk ncervar, som gjor at det er ingenting annet som teller.

Feg er veldig hverdagsmenneske. Jeg spør hva er vitsen. Feg har det ikke $i$ meg. Ideen ligger ikke $i$ meg. Er det ingenting du vil ha sagt så ikke prøv å gjør det. Ti still og gå hjem. (Forfatter, performer) 
Forfatteren, som arbeider dramaturgisk og performativt i en verdibasert kontekst, har ikke skapertrangen i seg selv, tenker han. Ønsket om å formidle og skape er knyttet til at det fins mottakere, som det han skaper er av betydning for. Når han først har klart for seg hva han vil formidle og for hvem, er den performative hendelsen så intensiv at plagsom øresus er borte mens han er utøvende. Verdigrunnlaget og ønsket om kommunikasjon og formidling løfter fram det sosiale som avgjørende for hans skapende prosesser. Steder og kroppsliggjøring eller fysisk nærvær er av avgiørende betydning for forfatteren og for performeren. For denne kunstneren er også mot og å tørre av stor betydning for selve utøvelsen, for det koster ham «ganske mye».

Narrativ vignett 4: Jeg har slik kraft i meg at den aldri tar slutt. Den føles som en sol inni meg.

Min biologiske mamma døde ved min fødsel. Hun var nyutdannet som tekstilkunstner, 23 år, da det gikk som det gikk $i$ hennes liv. Pappa giftet seg om igjen og jeg fikk søsken.Vi barn har alltid fätt leve i sterke fiktive verdener. Hele hjemmet var vår spilleplass, helt fra badstuen til foreldrenes soverom. Feg tror dette har påvirket meg sterkt. Det er underlig for jeg har slik kraft $i$ meg at den aldri tar slutt.

feg opplever ikke at jeg graver veldig dypt $i$ alle mulige spor $i$ meg. Men jeg opplever at jeg har en sterk kraft. Den foles som en sol inni meg. Det er som en stor klode av energi, her ved solar plexus. Feg tenker at jeg fikk også min biologiske mammas kraft. Den er som solen $i$ meg. Nesten som jeg skulle vare gravid. Hvis jeg har det kjempedårlig krymper solen en liten stund, men aldri lenge. Den driver på. Min datter sier at mamma kryper $i$ hop $i$ fosterstilling 20 minutter, når hun mår dårlig, aldri lenger. Feg har sterk billedhukommelse. Feg ser alltid helheter, men jeg er dårlig på detaljer. Feg husker lange fortellinger. Det er som om jeg skulle vare $i$ datid og fremtid på samme gang. Det er som veldig $i$ kroppen, men så kommer mitt intellekt inn og spiller kjempesterkt med. Og det som har drevet meg videre siden er, at jeg har vert veldig nysgjerrig på hvordan saker og ting henger sammen. Mange sier at den kraften er lek. feg har lett for å komme i flow, og kunstneren i meg hører dårlig på misunnelige stemmer. (Visuell kunstner)

Den visuelle kunstneren har en avgjørende betydningsfull erfaring med seg i sine skapende prosesser, nemlig det hun vet om at hennes fødsel samtidig ble morens død. Hun tenker at dette har gitt henne en enorm skaperkraft og livsvilje. Hun sier at hun føler at hun er i fortid og fremtid samtidig. Hennes barndom var også rik på estetiske erfaringer i et trygt sosialt fellesskap med søsken og hjemme samt i nærmiljøet. En sterk integritet som skapende kunstner og en nysgjerrighet på hvordan ting henger sammen, er sterke drivkrefter i skapende prosesser, men hun mener at hun «graver ikke dypt i alle mulige spor» i seg. Visuelle bilder og helheter stiger fram først. Disse leker hun med, dvs. hun eksperimenterer med sine erfaringer og minner. Den visuelle kunstneren beskriver det skapende som en sterk prosess: det er som «veldig i kroppen", men så spiller intellektet sterkt inn. Også McCormack (2014) beskriver kunstnerisk ferdighet som en ferdighet med mange lag ubevisst, bevisst og også 


\section{A.L. Østern}

avhengig av ytre faktorer. I den avsluttende seksjonen drøfter jeg hva strategien fortellingssammenstilling har bidratt til å synliggjøre i kunstnernes kunnskapslandskap.

\section{Unike kunnskapslandskap både personlige og profesjonelle}

Gjennom sammenstilling av fire fragmenter av skapende kunstneres livsfortelling om hva de vil nevne om ting i bakgrunnen som driver dem til å skape, og om hvordan de starter kreative prosesser og får ideer, har jeg kartlagt en rekke forhold av betydning knyttet til tid, kontekst/sted og sosialitet, som kan bidra til å se bredere på konteksten for den enkelte fortellingen, til å tenke dypere om dilemmaer, motstand og eksistensiell betydning, og til å skape og revidere fortellingene i fortellingskonstellasjonen. Jeg har også oppdaget at det tredimensjonale narrative rommet ikke rommer alle dimensjoner av kunstnernes fortellinger. De er grensesprengende $i$ forhold til i hvert fall to dimensjoner, som jeg kan tilføye basert på vignettene: en materialitetsdimensjon og en affektiv-eksistensiell dimensjon. I det følgende skaper jeg en fortelling om deltakernes kunnskapslandskap ut fra de individuelle fortellingene.

\section{Tidsdimensjonen}

Ideer kan finnes der mange år, før det blir et kunstnerisk produkt. Noen har hele tiden nye ideer, en rik kilde. Noen arbeider med en idé i mange år, og vet det blir noe. Noen nevner betydningen av å ha tid, mye tid. Den lineære tiden løses opp giennom fram-og-tilbake-hopp i tid. Ideene ruller gjennom tiden, også mot fremtiden. Ideer kan eksistere som "energiflyt» lang tid før de realiseres i et kunstnerisk produkt. Kunstnere opplever en helt annen tidsdimensjon når de skaper, enn en lineær tid.

\section{Kontekstdimensjonen}

Plasser og hendelser i barndommen har avgiørende betydning for enkelte kunstnere: at mor døde ved denne kunstners fødsel, at ekstrem nærsynthet i barndommen først ble oppdaget seint. Flere har vokst opp i en tid med stor frihet til å bevege seg, leke seg og undersøke verden. En konkret plass nevnes av noen som avgjørende for ideen. Å være, bo på en plass som har stor variasjon i farger og stemninger, har betydning for noen. For noen er det av avgiørende betydning å ha tilgang til studio og studiotid i ensomhet.

\section{Sosialitetsdimensjonen}

På godt og vondt spiller det sosiale sterkt inn i skapende prosesser. Savn av venner og støttespillere hindrer en del prosesser. Støtte fra hjem og omsorgspersoner giør at ferdigheter og mot til å skape, støttes. Noen skapende prosesser er helt definert av at det er et behov for produktet. Det fins en mottaker eller flere. Noen skapende prosesser er avhengig av at kunstneren gir seg hen til de andre i samspill og improvisasjon. Det er risikofylt. For noen er det å formidle for andre så sterkt at plagsom øresus forsvinner når fokus på formidlingen er total, men det kreves mot. En kunstner sier at kunstneren i meg hører dårlig misunnelige stemmer. For noen er skapende prosesser 
ensomme, langt ut i prosessen. Kunstnerne har dermed et stort behov ikke å være sosiale. De peker på et stort behov for det ensomme rommet. Alle må få være helt alene med sine ideer for å kunne tenke klart. De eksisterer i et spenningsfelt mellom å være hyperrelasjonelle og superensomme. For alle er intensivt nærvær i ulike former en betingelse for skapende prosesser.

\section{Materialitetsdimensjonen}

Å omgås med materialer og objekter fremstår som viktig i mange av fortellingene. Det kan være smaken av ord, Fosenfjellene, fiskene, fiskenett, den oransje fargen og det turkisblå havet, tilgang til studio og band, og clownenese. Materialene åpner opp for de kunstneriske prosessene.

\section{Den affektiv-eksistensielle dimensjonen}

For de fleste er den skapende prosessen så intensiv og gledefylt at tidsopplevelsen endres, man kan glemme tiden. Den personlige opplevelsen, følelsene, intensitetene er avgiørende viktige. For noen er den intensive gleden så sterk at en kunstner kan kjenne seg å være nær noe hellig, og noen sier at fasen med å kaste opp ideer er den beste. Det å skape betyr å lytte innover og utover kroppslig-affektivt med en eksistensiell meningsdimensjon som gir energi. Her kan det utemmede konkretiseres som et paradoks: frihet og evne til å vente inn formuttrykk er nødvendig for kreativitet, samtidig er trening og selvpålagte strenge rammer også nødvendige.

\section{Fortellinger om kunnskapslandskap i skapende prosesser}

Det narrative rommet avtegner seg som unikt forskjellig for hver enkelt kunstner, men sammen viser landskapene hvordan den enkelte kunstner er knyttet til impulser fra langt tilbake i tid og også til ideer som peker fremover. Det personlige profesjonelle kunnskapslandskapet er i stadig omformning, avhengig av materialitet på ulike måter: objekter, naturkultur, sansninger. Den affektiv-eksistensielle dimensjonen er av avgjørende betydning for deres meningsskaping, og de har behov både for ensomtid og for nære fellesskap. De skapende kunstnerne har ikke bare et sterkt engasjement og utholdenhet: de lever og ånder for kunsten.

\section{Sammenfattende konklusjon}

Den narrative tilnærmingen med bruk av strategien fortellingssammenstilling har fungert åpnende for forståelse av kompleksiteten og affektiviteten i kunstnernes begynnelser på skapende prosesser. Fortellingene er konkrete og forklarende om bakgrunn i den enkeltes liv og om hvordan kunstneriske ideer oppstår. Å jobbe med fortellingssammenstilling er også noe som rører ved meg som forsker: Jeg kan la meg selv være berørt av kraften i kunstnernes fortellingsfragmenter. Gjennom anknytning til performativ teori har verdigrunnen kunnet synliggiøres, liksom den etiske måten å forholde seg på, som et ønske om å bety noe for noen. Rammene for et 


\section{A.L. Østern}

tredimensjonalt narrativt rom viste seg å være for trange. Gjennom vekt på en performativ tilnærming i betydningen eksperimentering med erfaringer, har jeg kunnet utvide det narrative rommet og forstå mer av kompleksiteten i kunstneres kunnskapslandskap. Det narrative rommet er multidimensjonalt, foranderlig og flytende. Fortellingssammenstilling har gitt meg mulighet til å kunne se flere betydningslag $\mathrm{i}$ fortellingene. Jeg har kunnet tilføye to dimensjoner av stor betydning i det narrative rommet, nemlig en materialitetsdimensjon og en affektiv-eksistensiell dimensjon. Jeg ser disse dimensjonene som nødvendige for å synliggjøre kompleksiteten og styrken samt skapertrangen som søker form og uttrykk hos kunstnerne.

Et kritisk blikk på strategien om sammenstilling av de fire vignettene, viser for det første fragmenter av mer omfattende livsfortellinger, derfor kan jeg si at sammenstillingen er begrenset som fortellingssammenstilling. Allikevel er disse vignettene autentiske, det var slik kunstnerne uttrykte seg. I den forstand er fortellingsfragmentene utemmede. For det andre har jeg ikke sortert slik at fortellingene skulle bli koherente. Det er et bevisst valg, knyttet til ønsket om ikke å redusere kompleksitet. Jeg valgte fortellingsfragment ut fra dimensjonene tid, sted og sosialitet, som jeg vurderte kunne si noe om det kunnskapslandskap den enkelte kunstner eksperimenterte $i$ og formet $i$ sine prosesser i. Jeg har latt meg berøre av deres fortellinger, og dermed også av den rytme og den atmosfære de skapte i sine fortellinger. Jeg har løftet fram temaet tid som foranderlig. Kunstnerne har med seg både fortid, nåtid og fremtid og kan bevege seg mellom tidslagene. Jeg har vist hvordan temaer knyttet til affekt og kroppsstemninger veileder kunstneren i kunstneriske valg i prosessen. Jeg har gjort forsøk på å artikulere det som er på grensen til å være tenkt, det vil si affekter, og det betyr et forsøk på å artikulere at hver kunstner har et hovedtema knyttet til å ville bidra med noe inn i verden. Gjennom sin måte å være på i verden vil kunstneren forandre, bidra med relasjon og kritisk-etisk tenkning. Som kunstner må mot og risiko være en del av det å være skapende kunstner. Jeg har vært en performativ forsker gjennom den tekstuelle uttrykksfullhet jeg har tilført denne artikkelens formuttrykk som forfatter. Jeg har i denne avsluttende delen skapt en fortelling om skapende kunstneres personlige profesjonelle kunnskapslandskap gjennom å sammenfatte og tolke dimensjoner $i$ et narrativt rom bygd på fortellingssammenstilling.

\section{Forfatterpresentasjon:}

Anna-Lena Østern, pedagogie dr. og fil.lic., er professor i kunstfagdidaktikk (em.) ved Institutt for lærerutdanning ved NTNU. Hun var faglig leder for den nasjonale forskerskolen for lærerutdanning NAFOL i perioden 2010-2015. Med bakgrunn som professor i modersmålets didaktikk ved Åbo Akademi Universitet ivaretar hun en bred inngang til forskning fokusert på kommunikasjon og relasjon i utdanning. En mangeårig forskningsinteresse er knyttet til pedagogisk veiledning og til dramaturgi i didaktisk kontekst.

\section{Referanser}

Ayers, W. (1995). To become a teacher: Making a difference in children's lives. New York: Teachers College Press. Bendiksen, S.A. (2017). Tegnmakerens skrivelek En a/r/tografisk studie av en fireårings tegnmaking i mulighetsrike verksteder. InFormation fournal for Art and Research, Vol. 6 (1), 1-22. 
Chemi, T., Jensen, J.B. \& Hersted, L. (2014). Behind the scenes of artistic creativity. Processes of Learning, Creating and Organizing. New York: Peter Lang.

Clandinin, D.J. (2013). Engaging in narrative inquiry. Walnut Creek, California: Left Coast Press.

Clandinin, D.J. \& Connelly, F.M. (2000). Narrative inquiry: Experience and story in qualitative research. San Francisco: Jossey-Bass.

Clandinin, D.J. \& Connelly, F.M. (1995). Teachers'professional knowledge landscapes. New York: Teachers College Press.

Connelly, F.M. \& Clandinin, D.J. (1990). Stories of experience and narrative inquiry. Educational Researcher, 19(5), 2-14.

Craig, C. (2007). Story constellations. Teaching and Teacher Education 23, 173-188.

Emerald, E. \& Carpenter, L. (2017). Autoethnography: Is my Own Story Narrative Research? I R. Dwyer, I. Davis \& E. Emerald (Red.), Narrative Research in Practice (s. 27-46). Singapore: Springer.

Geertz, C. (1973). Interpretations of culture: Selected essays. New York: Basic Books.

Gergen, K.J. \& Gergen, M. (2018). The Performative Movement in Social Science. I P. Leavy (Red.), Handbook of Arts-Based Research (s. 54-67). New York: Guilford.

Gompertz, W. (2015). Think Like an Artist... and Lead a More Creative, Productive Life. UK: Penguin Random House.

Herman, L., \& Vervaeck, B. (2005). Vertelduivels. Handboek verhaalanalyse [Narrative devils. Handbook of narrative analysis]. Brussels, Belgium:VUBPress/Vantilt.

Kaihovirta-Rosvik, H. (2009). Images of imagination. (Diss.) Vasa: Åbo Akademi, Pedagogiska fakulteten.

McCormack, D.P. (2014). Refrains for Moving Bodies. Experience and Experiment in Affective Spaces. Durham og London: Duke.

Montuori, A. (2003). The Complexity of Improvisation and the Improvisation of Complexity: Social Science, Art and Creativity. Human Relations. Volume: 56 Issue: 2, 237-255. February 1, 2003. https://doi. org/10.1177/0018726703056002893

Riis, K. (2016). Designkundskabens DNA. Udforskning af designkundskab gennem designprocessen Mit DNA. (Diss.). Trondheim: Institutt for filosofi og religionsvitenskap, Norges teknisk-naturvitenskapelige universitet NTNU.

Ronsley-Pavia, M. \& Grootenboer, P. (2017). Insights into Disability and Giftedness: Narrative Methodologies in Interviewing Young People Identified as Twice Exceptional. I R. Dwyer, I. Davis \& E. Emerald (Red.), Narrative Research in Practice (s. 183-208). Singapore: Springer.

Sermijn, J., Devlieger, P. \& Loots, G. (2008). The Narrative Construction of the Self. Selfhood as a Rhizomatic Story. Qualitative Inquiry Vol. 14(4), 632-650. Doi 10.1177/1077800408314356. 